DOI: 10.22363/2312-9182-2019-23-2-328-343

\title{
Paving the way to the text: Forms and Functions of Book Titles in Translation
}

\author{
Christiane Nord \\ University of the Free State \\ 205 Nelson Mandela Dr, Park West, Bloemfontein, 9301, South Africa
}

\begin{abstract}
When we are looking at the books displayed in the window of a bookshop, what first catches the eye is the title. Titles pave the way to the text, even in a literal sense. In any case, they establish a first contact with a potential readership, informing them, for example, about the genre (novel, non-fiction, children's book) or the content of the book, praising its qualities, and, if all this raises the readers' interest, appealing to them to buy and later read the book, or even guiding their interpretation of the text. This shows how important it is that a title is apt to fulfil all these functions - an original title in its own culture, a translated title in the target culture. It is a well-known fact that translators do not normally have the last word in the process of deciding on the title of a book they have translated. Nevertheless, if they can offer good arguments for or against certain title formulations, they might at least be heard. At any rate, just pleading for a "faithful" translation of the original title will not do. There may be a lot of arguments - and not only linguistic ones - against a literal translation, with which translators have to be familiar. The following study is based on a corpus including titles of fictional, nonfictional and children's books in English, German, French and Spanish. After justifying the classification as titles as texts, and even a genre with its own culture-specific conventions, it aims at showing the forms and functions of book titles in order to provide a sound foundation for their translation, discussing some of the problems derived from this functional perspective.
\end{abstract}

Keywords: book titles, function, translation problems, genre conventions, textuality standards

\section{For citation:}

Nord, Christiane (2019). Paving the Way to the Text: Forms and Functions of Book Titles in Translation. Russian Journal of Linguistics, 23 (2), 328 -343. doi: 10.22363/2312-9182-2019-23-2-328-343.

\section{Путь к тексту: \\ лингвистические и функциональные особенности заглавий книг и способы их перевода}

\author{
Кристиане Норд \\ Университет Фри-Стейт \\ 205 Nelson Mandela Dr, Park West, Блумфонтейн, 9301, Южная Африка
}

\begin{abstract}
Аннотация
Когда мы смотрим на книги, выставленные в витрине книжного магазина, первое, что бросается в глаза, - это заглавия. Заглавия прокладывают путь к тексту — даже в буквальном смысле. В любом случае они обеспечивают первый контакт с потенциальной аудиторией, сообщая ей, в каком жанре
\end{abstract}


написана книга (роман, нон-фикшн, детская книга), раскрывая основное содержание книги или указывая на ее достоинства, и, если все это вызывает интерес потенциальных читателей, призывают купить книгу или даже настраивают на определенную интерпретацию текста. Все это указывает на важность выполнения заглавием оригинала и заглавием перевода всех этих функций в исходной культуре и в принимающей культуре, соответственно. Хорошо известно, что в решении вопроса о том, каким должно быть заглавие переведенного произведения, последнее слово остается вовсе не за переводчиками. Однако если они способны предложить убедительные аргументы за или против определенной формулировки заглавия, они могут быть, по крайней мере, услышаны. В любом случае настаивать на сугубой «верности» оригиналу вряд ли эффективно. Против буквального перевода может быть множество аргументов, и не только собственно лингвистических, и переводчик должен их иметь. В рамках проведенного исследования был изучен корпус заглавий художественных, нехудожественных и детских книг на английском, немецком, французском и испанском языках. В работе дается обоснование классификации заглавий как самостоятельных текстов, а также возможности рассмотрения заглавия как отдельного жанра, основанного на собственных культурноспецифических конвенциях, и ставится цель раскрыть особенности формы и функций заглавий книг с тем, чтобы создать основы для адекватного перевода заглавий. Кроме того, рассматриваются отдельные проблемы перевода заглавий с точки зрения функционального подхода.

Ключевые слова: заглавие, функиия, проблемы перевода, конвенции жанра, стандарты текстуальности

\section{Для цитирования:}

Nord, Christiane. Paving the Way to the Text: Forms and Functions of Book Titles in Translation // Вестник Российского университета дружбы народов. Серия: Лингвистика = Russian Journal of Linguistics. 2019. T. 23. No 2. C. 328 -343. doi: 10.22363/2312-9182-2019-23-2-328-343.

\section{INTRODUCTION}

Reading a translated title, we often ask ourselves (if we know the original) why the translation is not more (or less) literal - and why a particular translation that looks so different from the original still has such great impact (or vice versa).

\section{Examples:}

(1) Joseph Conrad: The End of the Tether / German: Das Ende vom Lied

(2) Daphne du Maurier: Frenchman's Creek/French: L'Aventure vient de la mer ou la Crique du Français / Spanish: La cala del francés / German: Die Bucht des Franzosen

(3) Harper Lee: To Kill a Mocking Bird / French: Ne tirez pas sur l'oiseau moqueur / Spanish: Matar un ruiseñor / German: Wer die Nachtigall stört / French, as a film: Du silence et des ombres

(4) Samuel Beckett: Mal vu, mal dit / English: Ill seen, ill said / German: Schlecht gesehen, schlecht gesagt / Italian: Mal visto, mal detto.

We will come back to some of these examples later.

A large percentage of the titles available on the book market are translations, particularly in the German-speaking area (e.g., 42.3 per cent of the German, compared to 15.7 per cent of the English fictional book titles in our corpus). It can be expected, therefore, that at least part of the expectations and ideas a "typical" reader has with regard to the form and functions of titles is determined by translated titles. Very often, readers are not aware of the fact that the title they are reading in a publisher's catalogue or in a book review is a translation. But even if they are, they will interpret any title on the basis of their intuitive knowledge about titles of certain book genres, which, of course, is culture-specific. 
In this regard, it may be interesting to note that most studies about titles, whether they are entertaining (Bergengruen 1950 or Barton 1968, 1984) or academic (Hoek 1981, Rothe 1970, 1986) indifferently cite original and translated titles as examples for certain title types or forms. In spite of Hoek's statement that "[f]ormulating a title for a text is a cultural process", the author mainly deals with the universals of the title (cf. Hoek 1981, XI).

This shows the responsibility translators have when they translate a title. Moreover, we have to ask how "universal" or "culture-specific" the effect of titles on their receivers really is. Translations can introduce new title types or transfer existing types on new genres, as Rothe $(1970,110)$ explains with regard to duplex titles.

The study is based on a corpus consisting of four parts in English, French, Spanish and German. One part of the corpus dates from 1987 and served as a basis for an earlier publication (Nord 1993), another part, slightly smaller, dates from 2017, because we wanted to see whether the genre conventions for these titles have changed in the meantime. After analysing the two parts, we found that the results were rather similar, which allowed us to merge the two parts into one and use the combined corpus for the quantitative data presented in this study.

Two aspects were important for the compilation of the corpus: Firstly, the corpus should be representative of a broad variety of topics and styles in order to have a reliable basis for the analysis of the conventions of the genre "title", and secondly, the material should be relevant for translation. Fictional, nonfictional and children's books are, in fact, often translated, as the catalogues of popular publishing houses clearly show, where translated and non-translated titles are listed alphabetically without any distinction. These catalogues therefore seemed to provide suitable data for the study. The 1987 part was in print only, the 2017 part is available online. The sources are listed in the bibliography.

Each corpus part included similar numbers of fictional, nonfictional, and children's book titles retrieved from the catalogues of publishing houses in the United Kingdom, France, Spain, and Germany. Cultural differences between the various countries where these languages are spoken, which may be considerable for other text types, could be neglected since books are rarely published for one country only.

The total number of titles is 13,868: 4,232 titles in English (30.5\%), 3,561 (25.7\%) in French, 2,868 (20.7\%) in Spanish, and 3,207 (23.1\%) in German. The proportion of translated titles is highest in the Spanish part (52.2\%), and lowest in the English part $(10.1 \%)$, with the French $(22.9 \%)$ and the German part $(31.8 \%)$ in the middle.

In our analysis, translated and non-translated titles are dealt with indiscriminately since they form the repertoire guiding the readers' expectations with regard to what a (good) title is or should be like. More often than not, readers who are not familiar with the "déformation professionnelle" of translators or translation scholars are not even aware of reading a translation.

\section{TITLES AS TEXTS}

\subsection{General considerations}

In ancient libraries, the scrolls stood in stands side by side, a parchment strip on the upper margin indicating the author and the contents. This strip was called "sillybos" in Greek, in Latin first "index" and then mostly "titulus". Later the indication 
of author and content was shifted to the end of the text, and then, by and by, also to the beginning of the text (for the history of the title cf. Schnitzler 1983, 4ff., Rothe 1986, $11 \mathrm{ff}$., and Wulff 1979). In modern language use, a title in the sense that matters here is "the name of a book, musical composition, or other artistic work" (COED 2011). In order to prevent unauthorised use, misuse, imitation or confusable determinations (cf. Wilpert 1961), titles are protected by copyright law in some countries (e.g. Switzerland) or by the Law Against Unfair Competition (e.g. Germany, Austria) if they have a clearly distinctive form (so-called "soft titles" like Collected Works are not protected). In other countries, like the United States, for example, copyright protection is not available for titles (see https://www.copyright.gov/circs/circ34.pdf, 17/06/2017: "The U.S. Copyright Office cannot register claims to exclusive rights in brief combinations of words such as: ... Titles of works"). However, the U.S. Patent and Trademark Office states that a trademark protects words, phrases, symbols or designs identifying the source of the goods or services of one party and distinguishing them from those of others. When a book title becomes successful enough to be considered a recognizable brand, it may be eligible for trademark protection.

Since many titles are rather vague (e.g. Collected Works) and do not allow an unequivocal identification of a work, it seems reasonable to include the author's (or, in the case of films, the director's) name in the "title unit". In this context, Rothe (1986: 13) mentions the meaning of the French word titre, which can include the author's name. Speaking about a book, the name of the author is often not mentioned explicitly, at least if the work is well known, whereas sometimes the author's name even forms part of the title, like in The Best of H. C. Artmann. On the spine of a book we usually find both author's name and title. This is how the examples will be quoted in this paper.

Title pages of books show that the functional unit "author's name + title" forms part of a larger unit which usually includes the name of the publishing house, year and place of publication, number of the edition, an indication of the genre (e.g., in $28.3 \%$ of the subtitles in German fiction, $75.3 \%$ of the subtitles of English fiction, $28.3 \%$ of the subtitles of French fiction, and $75.0 \%$ of the subtitles of Spanish fiction, according to the 1987 corpus, apart from many other books where it does not form part of the title but only of the front matter), sometimes the name of the translator, etc. This information is often subsumed under the term "front matter". Since the front matter does not normally belong to the responsibilities of a translator, it can be left out of consideration in this study.

The unit "author's name + title" can be regarded as an abbreviation of a "hyper sentence" (cf. Gülich/Heger/Raible 1979: 103), which for the present article might read as follows.

(5) I, Christiane Nord, as author, am presenting to you, esteemed readers, my considerations about titles as functional units under the title "Paving the way to the text".

This sentence, which is usually quoted in its abbreviated form, is an explicit signal that an offer of information is directed at a potential reader or listener (who will not necessarily accept it). This means that the title is located at a metalevel above that of the text, which is relevant for the question whether this metacommunicative unit is part of the text that it announces (the so-called co-text) or whether its status is that of 
an independent textual entity. I will try to briefly answer this question using De Beaugrande/Dressler's seven standards of textuality (1981: 7ff.), namely cohesion, coherence, intentionality, acceptability, informativity, situationality, and intertextuality.

\subsection{Cohesion}

In a unit as short as a title, explicit features of cohesion like recurrence or paraphrase will be difficult to find. However, all titles consisting of more than one word (and also some one-word titles, e.g. in languages which have nominal compounds, like German) present syntactic relations serving as cohesive devices.

\section{Example}

(6) Gilbert K. Chesterton: The Man who was Thursday (F))

(7) René Fallet: Mozart assassiné (F)

(8) Octavio Paz: Juntacadáveres $(\mathrm{F})$

In Example 6, the relative pronoun who is an anaphoric element referring back to the man). In Example 7, the past participle assassiné ("murdered") is in grammatical agreement with Mozart, and in Example 8, the Spanish compound consists of a verb form in the third person singular, junta ("it collects") and a noun as an object to the verb, cadáveres ("corpses"). Moreover, all functional title units show a cohesive relationship between the author's name and the title as such. In former times, the author's name was often formulated in the possessive case (e.g. in Latin). Today, this relationship is indicated by a colon or a comma or by the conventional layout on the title page, where the author's name is usually placed above or below the title phrase.

On the other hand, the title (as well as an abstract) and the co-text are not linked by cohesive devices. Recurrence and paraphrase, for example, do not bridge the gap between the two levels of communication. Using the title of this paper again, we will see that the first sentence of the co-text does not substitute the topical noun mentioned in the title by a pronoun, which would be the appropriate way of establishing cohesion:

\section{Example}

(9) Title: Paving the way to the text: forms and functions of book titles in translation. [Abstract] Co-text: *They are the first thing that catches the eye when...

Normally, a new referent is introduced with the indefinite article and afterwards substituted with the definite article. The definite article used in many titles indicates a reverse relationship, in which the title noun substitutes the referent mentioned in the text (cf. Hoek 1981: 162). This may be due, among other things, to the fact that in earlier times, the title was placed at the inner end of the scroll, i.e. at the end of the text.

\subsection{Coherence}

Recipients establish coherence between the concepts and relations expressed in a text either on the basis of cohesion or, if there are no cohesive devices, using their previous knowledge about the objects and phenomena mentioned in the text. In the case of titles, where cohesion, as we have seen, is rather limited, the latter will usually be the case. Recipients need an experience of titles in order to be able to recognize an utterance 
as a title, i.e. as a signal for an offer of communication about a text, and to make sense of the information given in the title. This experience often includes some knowledge about the author.

\section{Example}

(10) James Joyce: Ulysses (F) / German: Ulysses / French: Ulysse / Spanish: Ulises

(11) James Joyce: Finnegans Wake (F) / German: Finnegans Wake / French: La veillée des Finnegan / Spanish: Finnegans Wake

As far as Example 10 is concerned, English, French and Spanish readers will recall the Greek Myth, but German readers will find it difficult to make sense of the title because Ulysses is called Odysseus in German. In Example 11, the English formulation will trigger certain expectations as to the content of the novel, which also applies to the French translation, whereas German and Spanish readers will probably not find the non-translated title coherent with what they know about the world.

The "coherence" between the title and the co-text is of a different kind. Usually, we would expect that the title contains some indication of the topic or contents of the co-text, but this is not necessarily so.

\section{Example}

(12) Eugène Ionesco: La cantatrice chauve / English: The Bald Soprano / German: Die kahle Sängerin / Spanish: La cantante calva.

From Ionesco's title (Example 12), we expect the bald soprano to be the protagonist of the play, but she does not even appear on the scene and is only mentioned in passing. The title with its lack of coherence with the co-text indicates that Ionesco's play belongs to the so-called Theatre of the Absurd.

\subsection{Intentionality}

Intentionality means that authors or senders who produce a text usually have some communicative intentions in mind. These intentions can refer to both the title and the co-text, but in different ways. The title is intended to identify the co-text, provide some information about it, attract the attention of potential recipients, and establish a channel for communication with any interested readership. The co-text, in contrast, is an offer of information, in the widest possible sense (cf. Reiss/Vermeer [1984]2013: 69-74), about some object belonging to a (real or fictitious) world of objects and phenomena. This means that the title is intended to pave the way towards the co-text without yet being a part of it.

\subsection{Acceptability}

Recipients must be willing to make sense of a text (cf. De Beaugrande/Dressler 1981: 6). Therefore, they will try to understand even texts lacking cohesion or coherence. For the title, this willingness to understand is particularly important if it is elliptic or if it contains an allusion (Example 14).

\section{Examples}

(13) John Cleland: Fanny Hill, or Memoirs of a Woman of Pleasure /

(14) Robert Rankin, The Fandom Of The Operator 
This is the reason why acceptability standards are again different for titles and co-texts. On the one hand, certain linguistic "anomalies" are only acceptable in titles (cf. the duplex title in Example 13), and on the other hand, titles are only acceptable as "titles" if they are formulated in certain conventional ways.

\subsection{Informativity}

The standard of informativity refers to the expectedness or unexpectedness of the information given in an utterance. Titles are again a special case in this respect: the information about the co-text should be sufficient to characterize it and attract a reader's attention, but not too exhaustive because this would make reading superfluous. The particular informativity of the title should therefore spark the reader's interest in the co-text.

\subsection{Situationality}

It is obvious that title and co-text are located in different situations, although certain pragmatic factors may be the same (place, time, or medium of communication, particularly if the title serves as a "heading" above the co-text, cf. the list of extratextual factors in Nord [1991] 2005). They would be different if the title is listed in a publisher's programme or displayed over a theatre entrance. In any case, titles and co-texts are produced for different reasons: any event can serve as a motive for the production of the co-text, while the title is usually produced because there is a text that has to be made identifiable as intellectual property of its author (although there are quite few anecdotes about titles whose co-texts were never written).

\subsection{Intertextuality}

Intertextuality refers to any relationship between texts, both with regard to genrespecific features and concerning direct or indirect allusions to existing texts. Both forms of intertextuality are very frequent in titles. In spite of the apparent diversity of title forms, a thorough analysis of the corpus reveals that a small number of patterns is used again and again, often in correlation with co-text genres (Example 6). In contrast, title allusions and quotes are mainly used to enhance the appellative function of the title (Examples 7, 8, 14).

\section{Examples:}

(15) Gilbert K. Chesterton: The Man Who was Thursday / John Le Carré: The Spy Who Came In from the Cold

(16) Julio Cortázar: La vuelta al día en 80 mundos / Around the Day in Eighty Worlds cf. Jules Verne: Le Tour du monde en quatre-vingts jours / Around the world in 80 days.

(17) John Milton: Paradise Lost / Paradise Regained.

Intertextuality among titles ("intertitularity", cf. Hoek 1981:183 ff.) can be compared to intertextuality among other texts, whereas the relationship between titles and their co-texts cannot be regarded as intertextuality in this sense since the two are located at different levels, as we have seen before. The relationship between title and co-text is one of complementarity, which is not normally observed between two texts. 


\section{TITLES AS METATEXTS}

As we have seen, titles fulfil all standards of textuality, that is, they are texts that are located at a hyper-level above that of the co-text and not part of it. Since it is a text "about" another text, it can be regarded as "metatext", thus belonging to the same category as reviews or text commentaries. However, titles are different from these other metatexts in that they have a specific relationship with its object text, without which they cannot fulfil their function as titles.

Certain newspaper headlines, particularly in the case of so-called "hard news", cf. Lüger 1977: 266), may serve, together with their sub-headlines, as independent news texts, but if they are read as such, they lose their status as titles and receive a situationality of their own.

Therefore, the simultaneous "autonomie" and "dépendance" (Hoek 1981: 151) of the title vis-à-vis the co-text can be regarded as a specific characteristic of titles. The dependency does not seem to be unilateral. On the one hand, the form of the title is determined by certain features of the co-text (e.g., its affiliation to a genre), and on the other hand, the title itself guides the receivers in their reception and interpretation of the co-text. Moreover, this process is recursive: in some cases, having read the cotext may change the comprehension and interpretation of the title (cf. Schnitzler 1983: $2 \mathrm{f}$. and Rothe 1986: 4-7).

\section{TITLES AS FUNCTIONAL UNITS}

If the title is a text, it is used, like other texts, as an instrument of communication in a communicative interaction in which it is intended to achieve certain functions. As we have mentioned before, the title is intended to identify its object, the co-text, and make it distinguishable from other texts. This is what we would call a distinctive function, which usually corresponds to proper names.

A proper name is never totally arbitrary. Some names, which we call aptonyms or descriptive names, describe the object (e.g. "Holly Golightly" in Truman Capote's novel Breakfast at Tiffany's), others at least classify it (male vs. female personal names, geographical names like Mount Everest, Isle of Man, product names). The same applies to titles as names. They (implicitly or explicitly) describe or classify the co-text or inform about its topic (= referential function). Some titles express the sender's attitude towards the co-text (= expressive function). Titles establish a first contact with a potential receiver (= phatic function) and, if they are attractive enough, raise their interest and make them read, or listen to, the co-text and, in certain cases, even interpret it in a specific way (= appellative function).

The analysis of the corpus revealed that the distinctive and the phatic functions are common to all titles, whereas referential, expressive, and appellative functions are optional. There are titles without a referential or an expressive function, and others where the appellative function is not necessary because they are directed at an audience that has an interest in the co-text anyway (e.g. scholarly articles of a certain discipline). 


\section{TITLES AS A GENRE}

\subsection{General considerations}

As we have seen, the communicative interaction in which titles serve as instruments are rather standardized. Therefore, we may expect that, in the course of time, certain combinations of features also have become standardized, which allows us to speak of titles as a genre.

The diversity of possible title forms is not contradictory to this claim, as long as the basic pattern is the same for all titles. The constellation of functions results in particular linguistic features (like limited length, ellipsis, preference of nominal structures) and nonverbal characteristics (e.g., fonts, centre justification, layout on the title page) which are typical of titles.

According to the hierarchy of communicative functions and subfunctions, we might distinguish genre variants (cf. Reiß/Vermeer [1984] 2013: 155 ff.) like titles of nonfictional books, which are mainly referential, or mainly appellative newspaper headlines. In the following section, we will provide some examples for title conventions in our corpus, focussing on English titles.

\subsection{Title types - title forms - title patterns}

At first sight, we can distinguish four title types: simple titles, duplex titles, complex titles and title strings, each of these forms includes a number of patterns.

\subsubsection{Simple titles}

Simple titles consist of one single syntactic unit, whose length varies between a grapheme, a word or number, a main or subordinate clause or a compound, or combinations of numbers, words and clauses. Each simple title is structured according to the grammatical form it represents. Therefore, we can distinguish the following title forms: nominal titles (one or more noun phrases which may be complemented by various kinds of attributions), attributional titles (isolated attribution with or without complements), adverbial titles (adverb or adverbial phrase introduced by a preposition), verbal titles (infinite verb forms like infinitive, gerund, or participle with various kinds of complements), clausal titles (complete main or subordinate sentences or hypotaxis), and interjectional titles (interjections, salutations). Each title form can be subdivided into patterns, as shown in the following examples ${ }^{1}$ :

Examples:

(18) Erica Jong: Serenissima (F) — Nominal title, pattern: NP

(19) Gilbert K. Chesterton: The Man who was Thursday (F) - Nominal title, pattern: $\mathrm{NP}+$ rel.clause

(20) Rudyard Kipling: Recessional (F) - Attributional title, pattern: Attr-adj

(21) Sharpe: Just like a Girl (NF) - Attributional title, pattern: Attr-comp

(22) Gerald Seymore: At close quarters (F) - Adverbial title, pattern: Adv-loc

(23) P. Corder: Introducing Applied Linguistics (NF) - Verbal title, pattern: V+obj

${ }^{1}$ Each example is specified by a letter marking the genre (F[iction], NF[nonfiction], C[hildren's book], $\mathrm{P}[$ oetry]; $\mathrm{T}$ indicates that the title is a translation. For the patterns, we use acronyms: $\mathrm{NP}=$ noun phrase, $\&=$ conjunction like and $, o r, v s, \mathrm{mCl}=$ main clause, $\mathrm{subCl}=$ subordinate clause, part $=$ participle. 
(24) Gena Turgel: I Light a Candle (F) - Clausal title, pattern: $\mathrm{mCl}$

(25) Georges Mikes: How to Be Decadent (F) - Clausal title, pattern: subCl

(26) Peter Ustinov: Dear Me (NF) - Interjectional title, pattern: Exclamation

(27) James Morris: Farewell the trumpets (F) - Interjectional title, pattern: Salutation

Nominal simple titles are the most frequent title type in all parts of the corpus. However, they are less frequent in the titles of children's books, where clausal titles represent $12.5 \%$ in the English corpus and even $21.1 \%$ in the German corpus.

If we look at the nominal simple titles more closely, we find that the pattern NP (with definite article) is most frequent in fictional book titles $(11.8 \%)$, whereas it only represents $1.5 \%$ in nonfictional book titles, where NP\&NP is the pattern with the highest frequency $(20 \%)$, which only amounts to appr. 5\% in fictional book titles. For this pattern, we can also observe a semantic difference between genres: In fictional titles, the NPs usually refer to persons (e.g., Mark Twain: The Prince and the Pauper), while the NPs in nonfiction more often refer to abstract concepts (e.g., Hans Georg Gadamer: Truth and Method).

\subsubsection{Duplex titles}

Duplex titles are a historical form that is still relatively popular today. It used to be typical of theatre plays, but nowadays it is also used for other genres, e.g. nonfictional or children's books. The two parts of the duplex title, which could each be complete simple titles and are related by a kind of semantic tension, are connected by the disjunctive connector or/ ou / o / oder (see also Example 2).

Examples:

(28) Robert Darnton The Devil in the Holy Water, or the Art of Slander from Louis XIV to Napoleon (NF)

(29) Christine Nöstlinger: Konrad o el niño que salió de una lata de conservas (C, T) / German original: Konrad oder Das Kind aus der Konservenbüchse / English: Conrad: The Factory-Made Boy

It may be interesting to note that there are no duplex titles in the English corpus of children's books. The only duplex title in the Spanish corpus of children's books is a translation from German (Example 29).

\subsubsection{Complex titles}

Complex titles also consist of various parts, one main title and usually one, sometimes two or even three subtitles. Main title and subtitle(s) are not connected by lexical means (in catalogues, we find either a full stop or a colon between them), and like in duplex titles, the title parts do not form a text, i.e. they are not linked by cohesive devices like pronominal substitution or anaphora. Quite often, the subtitle includes an explicit or implicit indication of the genre to which the co-text belongs.

\section{Examples:}

(30) Arthur Miller: Timebends. A Life (F)

(31) Kimberly Dean: High School Reunion: A Rouge Erotic Romance (F)

(32) James Delbourgo: Collecting the World: The Life and Curiosity of Hans Sloane (NF)

(33) Jojo Moyes: Honeymoon in Paris and Other Stories (F) 


\subsubsection{Title strings}

Books which include two or more independent narrations sometimes have titles formulated in strings, either asyndetic (in Spanish and English) or connected by and (in English) or by suivi de or précédé de (in French).

\section{Examples}

(34) Catherine Cookson: Heritage of Folly / The Fen Tiger (F)

(35) Fyodor Dostoyevsky: The Double and The Gambler (F, T)

(36) Miguel de Unamuno: San Manuel Bueno, mártir. Cómo se hace una novela (F)

(37) Friedrich Nietzsche: Le Cas Wagner suivi de Nietzsche contre Wagner (NF, T)

In the German corpus, title strings are usually replaced by complex titles consisting of a main title referring to the most important or longest of the included texts and a subtitle like ... and other stories/essays.

\subsection{Form - function - genre}

There seems to be a genre-typical relationship between form and function. For example: the longer a title, the weaker its appellative effect. Articles in specialized journals very often have long complex titles describing the topic or the content as exactly as possible. In these cases, the constellation of situational factors does not require a strong appellative function because the previous interest of the addressed audience of such texts can be expected to be strong enough to make appellativity in the title superfluous.

\section{TRANSLATION PROBLEMS IN TITLE TRANSLATION}

\subsection{General remarks}

In the following section, we will briefly look at some translation problems related to the communicative functions of titles.

\subsection{Translating the distinctive function}

In order to achieve a distinctive function, a title must be a unique name unmistakably identifying the co-text. A title formulation that is distinctive in the source-culture repertoire may be non-distinctive in the target culture (or vice versa).

\section{Examples}

(38) Peter Weiss: Das Duell (F) / Anton Tchekhov: Das Duell (F, T)

(39) Tanja Blixen: Out of Africa (F, T) / Ihabvala: Out of India (F)

(40) Joseph Campbell: The Masks of God: Creative Mythology / The Masks of God: Occidental Mythology / The Masks of God: Oriental Mythology (NF)

(41) John Milton: Paradise Lost / Paradise Regained (F)

In Example 38, the translation of Anton Tchekhov's text cannot be distinguished from the German original text by Peter Weiss. In Example 39, two translations from different source cultures are competing in the English corpus.

Some titles are intended to establish an intertextual link with another title by the same author, e.g. using the same main title with another subtitle (Example 40), or titles referring to each other (Example 41). 


\subsection{Translating the phatic function}

The phatic function of a title depends on its length and its mnemonic quality, which is often strengthened by the use of familiar title patterns or other forms of intertextuality. The corpus reveals that the average length of a main title is between three or four words, independently of the structures of the respective languages. Longer titles are made easier to remember by using original structures, catchy words, or a rhythmical pattern.

\section{Examples}

(42) Amos Tutola: The palm-wine drinkard and his dead palm-wine tapster in the deads' town (F) / German: Der Palmwein-Trinker. Ein Märchen von der Goldküste ["The palm-wine drinkard. A tale from the Gold Coast"]

(43) C. Nord: Textanalyse und Übersetzen (NF) / English: Text Analysis in Translation / Spanish: Texto base - texto meta. Un modelo de análisis pre-traslativo

The German translation of Tutola's title (Example 42) uses a subtitle to shorten the main title and to indicate that the author is African. The problem here is that the story based on Yoruba folk tales is not set in the Gold Coast but in Nigeria.

The English translations of my own book (Example 43) was adapted to title conventions, since in English the nominal pattern NP\&NP is much less frequent than in German, whereas the most frequent pattern in English nonfictional titles is NP+prepositional phrase. In Spanish, a literal translation of the German original title would have been far too long ("El análisis del texto y la traducción"), therefore, I have chosen a complex title ("Source text - target text. A model for pre-translational text analysis"), shifting the referential function to the subtitle and thus making the main title more acceptable.

\subsection{Translating the referential function}

In order to achieve the referential function, a title must be comprehensible and informative for its readers. Comprehension relies on culture-specific background knowledge. This is particularly important for intertextual allusions, as in Example 44, which alludes to the Gospel of Matthew (26:34).

\section{Examples}

(44) Cesare Pavese: Prima che il gallo canti (F) / French: Avant que le coque chante / English: Before the cock crows

(45) Thomas Mann: Lotte in Weimar (F) / English: The Beloved Returns: Lotte in Weimar / French: Charlotte à Weimar

For educated German readers, the reference to Weimar and Lotte in Example 45 points to Johann Wolfgang von Goethe and his famous relationship with Charlotte Buff. This would not work for English speaking readers, but there may be some doubts as to whether the new main title really conveys a referential function, although it is certainly more appellative.

\subsection{Translating the expressive function}

In order to achieve the expressive function, a title must be in accordance with the value system of the addressed audience or make any different value system explicit. Since the expressive function is sender-related, it is the translator's responsibility to respect the intention of the author. 


\section{Example}

(46) Alan Paton: Cry, the Beloved Country (F) / German: Denn sie sollen getröstet werden ["For they shall be comforted", Matthew 5:4] / French: Pleure, ô pays bien-aimé

The original title of the book by Alan Paton, which deals with apartheid in South Africa, expresses the author's sorrow for his country. The German title, in contrast, expresses the confidence that all will be well in the end.

\subsection{Translating the appellative function}

The appellative function serves to make the title attractive for a potential readership and may also guide the readers' interpretation of the text. What is attractive for a sourceculture readership may not necessarily be attractive for an audience in the target culture.

Examples

(47) William Faulkner: The Sound and the Fury (F) / German: Schall und Wahn / French: Le bruit et la fureur / Spanish: El sonido y la furia

(48) Thornton Wilder: The Skin of our Teeth (F) / German: Wir sind noch einmal davon gekommen / Spanish: La piel de nuestros dientes [literal translation]

Intertextual relations which make the source title attractive, may not "function" in another culture. The allusion to Macbeth in Example 47 will probably not be recognized by German, French, or Spanish readers, who are not so familiar with Shakespeare. And the literal translation of the English idiom to escape by the skin of one's teeth in Example 48 does not make any sense to Spanish readers, whereas the German title alludes to the equivalent German idiom.

\section{CONCLUDING REMARKS}

The main hypotheses of this paper were the following:

- titles are texts which are intended to achieve the same communicative functions as other texts;

- since titles are generally used for a particular set of functions, they can be regarded as a genre and, as such, show certain genre-typical structures which can be described with regard to their form, distribution, and frequency;

- these genre conventions are culture-specific;

- the study of these conventional features may be of help in the process of title translation or translation criticism;

- the methodology used for the analysis of title translation can serve as a paradigm for a functional translation of other texts or text types.

As we have seen from the analysis of the corpus, titles are texts, whose genrespecific functions and features prepare the reader for the reception of the co-text. In this sense, they guide the audience's interpretation, "paving the way" to the text.

Titles can be regarded as texts forming a text type or genre, and as such, they represent conventional forms and patterns like any other text type. Titles can be regarded as a paradigmatic case for functional translation, where the target text is expected to achieve certain communicative functions for the target audience, which may or may not be the same as the ones the source text was expected to achieve for the source-culture audience. 
Therefore, titles are also interesting from a translation-studies point of view. In the late 1980s and early 1990s, when I started to study this phenomenon, hardly anyone had dealt with titles in depth. Titles were sometimes mentioned as examples (e.g. Toury 1980, 103-105, Neubert 1985, 106ff.) or compared with their translations (Aubrun 1980, Boehlich 1977), but not really problematized as such. Some literary scholars discussed isolated aspects of titles or criticized certain title translations (cf. Schober 1982, Monterroso 1982, Riesz 1985), and the translation scholar Peter Newmark (1981, 159) dismissed the problem "Headings and Titles" with a few rules:

These should normally be translated last. A non-literary text should normally be factually and accurately described by its title. A literary text may have its title changed to an appropriate connotation. Usually, the translator has control of the title of any text. A heading is static, and describes a finished narration: it should normally be centred on one or two nouns, and have SL verbs converted to present or past participles qualifying them. Thus "Vance sucht in Westeuropa Unterstützung für neue Schritte gegen Iran" might become "Vance's attempt to get renewed Western European support against Iran". (My emphasis)

It is time, therefore, to analyse the criteria for the translation of titles in more detail. Thanks to their limited length and their conciseness, titles may be regarded as independent translation units. There are three aspects that play an important role in this endeavour: Firstly, the situationality of a title, determined by such extratextual factors as medium, time, place or motive of production and reception, is easier to grasp than that of a long and complex text which may contain many different translation-relevant aspects. Secondly, it is obvious that, for a title, audience and function orientation is extremely important. And last, but not least, it seems equally plausible that a translated title must be appropriate to achieve the desired functions in the title corpus of the target culture and that therefore (formal) fidelity or faithfulness with regard to the source-text title, which in any case was formulated for the source culture, has to be subordinated to functionality. Functional considerations may, therefore, help the translator to find a title translation which will be apt to fulfil the intended functions in the target culture.

(C) Christiane Nord, 2019

\section{REFERENCES}

Aubrun, Charles (1980). Traduire les titres. Parallèles. Cahiers de l'École de Traduction et de l'Interprétation 3 (1980), 31-35.

Barton, Walter (1968). Denn sie sollen gelesen sein. Kleine Stilfibel des deutschen Buchtitels. Hamburg: Furche.

Barton, Walter (1984). Der Zweck zeitigt die Titel. Kleine Kulturdunde des deutschen Buchtitels. Siegen: Universität.

Bergengruen, Werner (1950). Titulus. Das ist: Miszellen, Kollektaneen und fragmentarische, mit gelegentlichen Irrtümern durchsetzte Gedanken zur Naturgeschichte des deutschen Buchtitels oder Unbetitelter Lebensroman eines Bibliotheksbeamten. Munich: Nymphenburger Verlagsanstalt.

Boehlich, Walter (1977). Beliebigkeit der Form. "Die andere Seite des Lebens" von Vargas Llosa. Neue Rundschau 88, 461—433. 
De Beaugrande, Robert A. / Dressler, Wolfgang (1981). Introduction to text linguistics. LondonNew York: Routledge.

COED 2011 = Concise Oxford English Dictionary. Oxford: University Press.

Gülich, Elisabeth / Heger, Klaus / Raible, Wolfgang (1979). Linguistische Textanalyse. Hamburg: Buske.

Hoek, Leo H. (1981). La Marque du Titre. The Hague: Mouton.

Lüger, Heinz-Helmut (1977). Journalistische Darstellungsformen aus linguistischer Sicht. (Diss.) Freiburg.

Monterroso, Augusto (1982). Sobre la traducción de algunos títulos. In Augusto Monterroso: La palabra mágica. Mexico: Ediciones Era, 89-96.

Neubert, Albrecht (1985). Text and Translation. Leipzig: Enzyklopädie.

Nord, Christiane ([1991] 2009). Text Analysis in Translation. Leiden: Brill.

Nord, Christiane (1993). Einführung in das funktionale Übersetzen. Am Beispiel von Titeln und Überschriften. Tübingen: Francke.

Reiss, Katharina / Vermeer, Hans J. ([1984] 2013). Allgemeine Grundlegung einer Translationstheorie. Tübingen: Niemeyer. In English: Towards a General Theory of Translational Action. LondonNew York: Routledge, 2013.

Riesz, János (1985). Anglophone und frankophone afrikanische Romantitel in deutscher Übersetzung. Die Neueren Sprachen 84:1 (1985), 5-18.

Rothe, Arnold (1970). Der Doppeltitel. Zu Form und Geschichte einer literarischen Konvention. Wiesbaden: Akademie der Wissenschaften.

Rothe, Arnold (1986). Der literarische Titel. Funktionen, Formen, Geschichte. Frankfurt a. M.: Klostermann.

Schnitzler, Marion (1983). Die Kapitelüberschrift im französischen Roman des 19. Jahrhunderts Formen und Funktionen. Heidelberg: Winter.

Schober, Rita (1982). Probleme literarischer Übersetzung am Beispiel der Titelübersetzung von Zolas 'Rougon Macquart'. In: Abbild, Sinnbild, Wertung. Aufsätze zu Theorie und Praxis literarischer Kommunikation. Berlin-Weimar: Aufbau-Verlag, 308-345.

Toury, Gideon (1980). Translational solutions and translational relationships. Toward the description of translated texts. In: In Search of a Theory of Translation. Tel Aviv: University, 89-111.

Wilpert, Gero von (1961). Sachwörterbuch der Literatur. Stuttgart: Metzler.

Wulff, Hans J. (1979). Zur Textsemiotik des Titels. Münster: Münsteraner Arbeitskreis für Semiotik. [papmaks, 12.1]

\section{Corpus material}

English

F/E: Penguin Stocklist 1988; Claude Gill Bookshops: Guide to Autumn and Winter Books 1987; https://www.penguinrandomhouse.com/books (2017): Fiction, Nonfiction, Children's Books

NF/E:. https://www.nytimes.com/books/best-sellers/paperback-nonfiction/ (2017)

C/E: Penguin Stocklist 1989; http://fdslive.oup.com/www.oup.com/oxed/children/oup_stocklist_ 2017 compressed.pdf?region=international (2017)

\section{French}

F/F: Folio Gesamtverzeichnis 1987 (Fiction). http://www.folio-lesite.fr/Catalogue/Folio/Folio (2017): Líttérature, Histoire et Sciences humaines. 
NF/F: Folio 1987 (Folio actuel, Folio essais, Folio histoire); Champs Flammarion 1989 Nonfiction); Armand Colin Lettres, Sciences Humaines.

C/F: Castor Poche Flammarion 1990.

\section{Spanish}

F/S, NF/S: Alianza Editorial Catálogo general 1987; https://www.alianzaeditorial.es/index.php (2017), Libros de bolsillo

C/S: Anaya, Co!. Luna de Papel, Catálogo 1988 (Libros infantiles y juveniles); Alf aguara Catálogo 1988 (Libros infantiles y juveniles; all original titles plus 51 translated titles 9n order to obtain a reasonable mixture); Christmas catalogue of Spanish book shops 1987 (only original titles, various publishers). http://www.smliteratura.com.ar/wp-content/uploads/ catalogo/Lij_Infantil_2017.pdf; https://www.anayainfantilyjuvenil.com/colecciones.php (2017); https://www.anayainfantilyjuvenil.com/ colecciones.php

\section{German}

F/G, NF/G: Suhrkamp/Insel Gesamtverzeichnis 1987; https://www.rowohlt.de/Buecher/belletristik/ literatur-nach-1960 (2017); https://www.suhrkamp.de/download/Gesamtverzeichnisse/TB Gesamtverzeichnis_2011.pdf (2017); https://www.suhrkamp.de/download/Vorschauen/ Insel_aktuell.pdf(2017)

C/G: dtv-junior Gesamtverzeichnis 1987; https://www.dtv.de/buecher/kinderbuch/c-30 (2017)

\section{Article history:}

Received: 28 December 2018

Revised: 21 February 2019

Accepted: 15 March 2019

\section{История статьи:}

Дата поступления в редакцию: 28 декабря 2018

Дата принятия к печати: 15 марта 2019

\section{Bionote:}

CHRISTIANE NORD is professional translator, $\mathrm{PhD}$, Habilitation, Dr. honoris causa (mult) translation scholar specialised in translation pedagogy. Author of 200 publications about theoretical, methodological and pedagogical aspects of "functionalism" in translation. As from 2007, research associate and professor extraordinary of the University of the Free State, Bloemfontein, South Africa.

Contact information: e-mail: post@christiane-nord.de

\section{Сведения об авторе:}

КРИСТИАНЕ НОРД - профессор, доктор, переводчик. Автор 200 публикаций о теоретических, методологических и педагогических аспектах «функционализма» в переводе. С 2007 года научный сотрудник и почетный профессор Университета Фри-Стейт, Блумфонтейн, Южная Африка.

Контактная информация: e-mail: post@christiane-nord.de 